7 Abrams, G P, and Bishop, J E, Proceedings of the Society of Experimental Biology, 1967, 126, 301.

${ }^{8}$ Drew, R, Dixon, K, and Samuel, E, Lancet, 1947, 1, 129.

${ }^{9}$ O'Brien, W, Proceedings of tropical medicine conference at the Royal College of Physicians of London, 1967, pp 86-95. London, Pitman Medical.

10 Cook, G C, British Medical fournal, 1978, 2, 238.

1 Bloom, S R, Gut, 1972, 13, 520.

12 Jacobs, L R, et al, Clinical Science and Molecular Medicine, 1976, 50, 14.

${ }_{13}$ Christofides, N D, et al, Gastroenterology, 1979, 76, 903.

${ }^{14}$ Vantrappen, G, et al, American fournal of Digestive Diseases. In press.

${ }^{15}$ Russell, R C G, et al, Postgraduate Medical fournal, 1976, 52, 645.

16 Adrian, T E, et al, Gut, 1976, 17, 940.

17 Bloom, S R, Mitznegg, P, and Bryant, M G, Scandinavian fournal of Gastroenterology, 1976, 11, Suppl No 39, p 47.

18 Bloom, S R, Turner, R C, and Ward, A S, Gastroenterology, 1977, 72, 813.

19 Alford, F P, Bloom, S R, and Nabarro, J D N, Diabetologia, 1977, 13, 1.

${ }^{20}$ Blackburn, A M, and Bloom, S R, fournal of Endocrinology. In press.

${ }^{21}$ Hoffman, W S, fournal of Biological Chemistry, 1937, 120, 51.

22 Calloway, D H, and Murphy, E L, Annals of the New York Academy of Sciences, 1968, 150, 82.

${ }^{23}$ Levitt, M D, New England fournal of Medicine, 1969, 281, 122.

24 Ridley, M J, and Ridley, D S, fournal of Clinical Pathology, 1976, 29, 30.

${ }^{25}$ Brown, J C, Cook, M A, and Dryburgh, J R, Gastroenterology, 1972, 62, 401.
${ }^{26}$ Lin, T-M, and Chance, R E, in Gut Hormones, ed S R Bloom, p 242. Edinburgh, Churchill Livingstone, 1978.

${ }^{27}$ Carraway, R, and Leeman, S E, Fournal of Biological Chemistry, 1975, 250, 1907.

${ }^{28}$ Carraway, R, and Leeman, S E, Fournal of Biological Chemistry, 1976, 251, 7045.

${ }^{29}$ Brown, J C, et al, in Gut Hormones, ed S R Bloom, p 277. Edinburgh, Churchill Livingstone, 1978.

30 Moody, A J, Jacobsen, H, and Sundby, F, in Gut Hormones, ed S R Bloom, p 369. Edinburgh, Churchill Livingstone, 1978.

${ }^{31}$ Walsh, J H, and Grossman, M I, New England Fournal of Medicine, 1975, 292, 1377.

32 Greenberg, G R, et al, Lancet, 1978, 2, 1280.

${ }^{33}$ Bloom, S R, et al, Gastroenterology, 1979, 76, 1102.

${ }^{34}$ Morson, B C, and Dawson, I M P, Gastrointestinal Pathology, p 314. Oxford, Blackwell Scientific, 1972.

${ }^{35}$ Mathan, V I, in Gastrointestinal Disease, ed $\mathrm{M} \mathrm{H}$ Sleisenger and J S Fordham, p 978. Philadelphia, Saunders, 1973.

${ }^{36}$ Besterman, H S, et al, Lancet, 1978, 1, 785.

37 Besterman, H S, et al, Gut, 1978, 19, 10.

${ }^{38}$ Barry, R E, et al, American fournal of Clinical Nutrition, 1977, 30, 32.

${ }^{39}$ Besterman, H S, et al, Gut, 1978, 19, 10.

${ }^{40}$ Holst, J J, et al, Scandinavian fournal of Gastroenterology, 1979, 14, 205.

${ }^{11}$ Ruppin, H, et al, Scandinavian fournal of Gastroenterology, 1975, 10, 199.

\title{
Pathogenesis of neonatal hyperbilirubinaemia after induction of labour with oxytocin
}

\author{
PETER C BUCHAN
}

British Medical fournal, 1979, 2, 1255-1257

\section{Summary and conclusions}

To determine the pathogenesis of neonatal hyperbilirubinaemia after oxytocin-induced labour venous cord blood from 95 healthy newborn infants was examined. Of these, 15 were delivered by elective caesarean section, 40 after spontaneous labour, and 40 after oxytocininduced labour. There was no significant difference in any haematological or biochemical variable between the first two groups. Infants born after oxytocin-induced labour, however, showed clear evidence of increased haemolysis associated with significantly decreased erythrocyte deformability $(P<0.001)$. In-vitro studies showed a time- and dose-related reduction in erythrocyte deformability in response to oxytocin.

The findings suggest that the vasopressin-like action of oxytocin causes osmotic swelling of erythrocytes leading to decreased deformability and hence more rapid destruction with resultant hyperbilirubinaemia in the neonate.

\section{Introduction}

The association between oxytocin-induced labour and neonatal hyperbilirubinaemia is well documented, ${ }^{1-8}$ suggested causes including hepatic glucuronyltransferase immaturity, ${ }^{5}$ anoxic

\footnotetext{
St James's University Hospital, Leeds LS9 7TF

PETER C BUCHAN, BSC, MRCOG, senior registrar in obstetrics and gynaecology
}

liver damage, ${ }^{6}$ enhanced placentofetal transfusion, ${ }^{7}$ increased erythrocyte fragility, ${ }^{8}$ and mechanical trauma to erythrocytes. ${ }^{4}$ I began the following study after the observation that fetal erythrocytes were less deformable after oxytocin-induced labour than after spontaneous labour. Erythrocyte deformability is an important determinant of erythrocyte life $\operatorname{span},{ }^{910}$ and in several conditions decreased deformability results in increased haemolysis. ${ }^{112}$ I therefore investigated the effect of oxytocin on erythrocyte deformability both in vivo and in vitro and sought evidence of fetal erythrocyte destruction during both spontaneous and induced labour.

\section{Patients and methods}

The study group comprised 95 healthy newborn infants ( 44 boys, 51 girls) with birth weights of 3005-4108 $\mathrm{g}$ (mean $3420 \mathrm{~g}$ ) and Apgar scores exceeding 7 at one minute. With use of a wide-bore needle and gentle suction to avoid haemolysis $20 \mathrm{ml}$ venous cord blood was collected as soon as the cord had been clamped and divided and before placental separation. The blood was anticoagulated with lithium heparin.

Of the 95 infants, 40 had been delivered after spontaneous labour and 40 after induction of labour by amniotomy and intravenous oxytocin (Syntocinon). The average dose of oxytocin used was $4500 \mathrm{mU}$ (range $3000-7000 \mathrm{mU}$ ). In the cases selected for study the duration of labour was between six and 14 hours and analgesia was achieved with intramuscular pethidine. No patient was given epidural analgesia. In none of the cases was there clinical or cardiotocographic evidence of fetal distress, and all mothers had spontaneous vertex deliveries. The remaining 15 infants were delivered by elective caesarean section.

Within two hours after delivery the following procedures were carried out on the cord blood: packed cell volume was measured with a Hawksley microhaematocrit; plasma osmolality was measured with an advanced osmometer; and erythrocyte deformability was measured by a microfiltration technique ${ }^{13}$ whereby the erythrocyte deformability index (EDI) was calculated as the volume of erythrocytes contained in a $20 \%$ suspension in their native plasma that 
passed through a Nuclepore filter ( $5, \mathrm{~m}$ diameter) in one minute under a filtration pressure of $20 \mathrm{~cm} \mathrm{H}_{2} \mathrm{O}$. Plasma aliquots were stored at $-20 \mathrm{C}$ until all samples were collected and then estimated in a batch for bilirubin concentration by a standard autoanalytical method, for haptoglobin concentration with M-partigen haptoglobin plates (Behring Diagnostics), and for lactate dehydrogenase activity (normal range in our labcratory 70-240 IU l) by the method of Wroblewski and La Due."

In-vitro studies were made on fetal cord blood. In the first experiment $3000 \mu \mathrm{U}$ oxytocin was added to $2010-\mathrm{ml}$ aliquots of erythrocyte suspension, and 500 ul isotonic saline was added to a duplicate $2010-\mathrm{ml}$ aliquots prepared from the same cord blood. The samples were incubated at $37 \mathrm{C}$ and the EDI of the two sets measured at intervals. In the second experiment $505-\mathrm{ml}$ aliquots of erythrocyte suspension were prepared and $500: \alpha$ isotonic saline and $500: \curlywedge \mathrm{U}$, $1500: \imath \mathrm{U}, 2500: \mathrm{U}$, and $4000: 2 \mathrm{U}$ oxytocin respectively added to groups of 10, which were then incubated for four hours and the EDI of each sample measured.

\section{Results}

The table gives the haematological and biochemical values in cord blood from the 95 infants. There was no significant difference in any variable between infants delivered by caesarean section and those born after spontaneous labour. Infants born after oxytocininduced labour, however, had a lower packed cell volume $(P<0.001)$, increased plasma bilirubin concentration $(\mathbf{P}<0 \cdot 001)$, decreased plasma haptoglobin concentration $(\mathbf{P}<0.01)$, and increased plasma lactate dehydrogenase activity $(P<0 \cdot 001)$. These infants also showed a

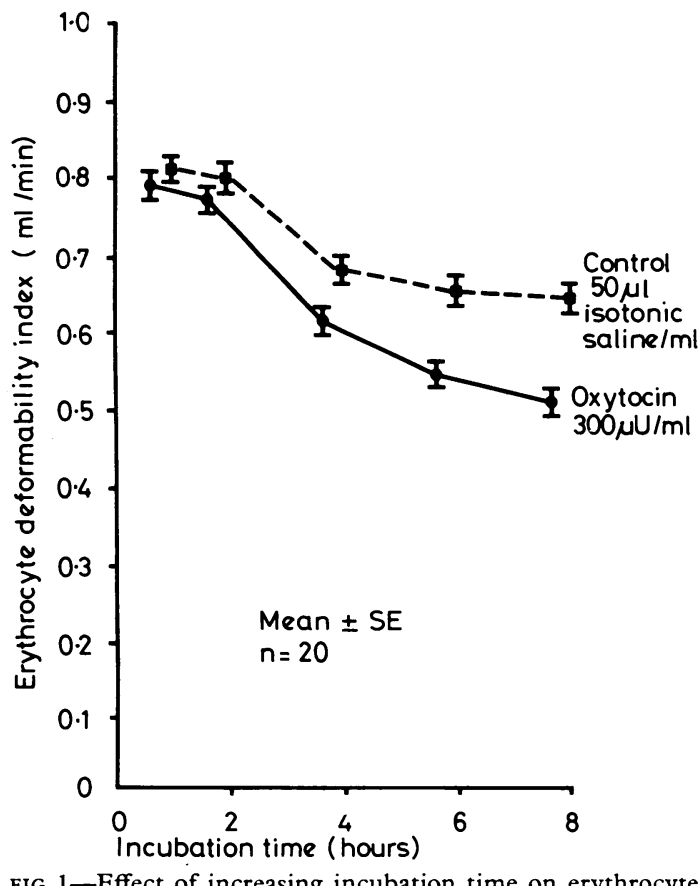
deformability.

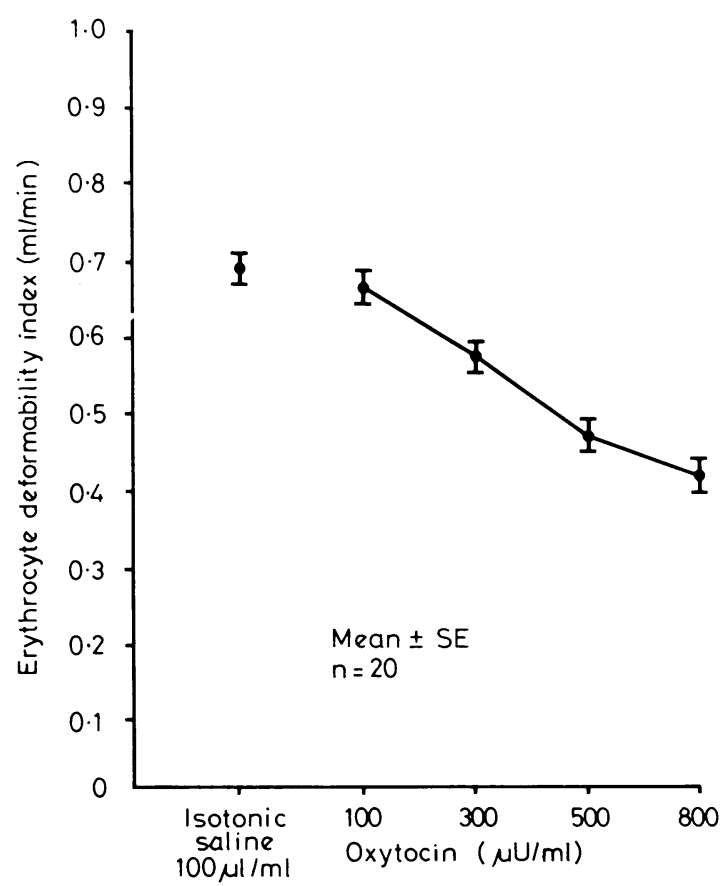

FIG 2-Effect of increasing oxytocin dosage on erythrocyte deformability.

Mean $( \pm S E)$ haematological and biochemical values in cord blood from infants delivered by elective caesarean section and after spontaneous and oxytocin-induced labours. Numbers of infants given in parentheses

\begin{tabular}{|c|c|c|c|c|}
\hline Cord blood & Elective caesarean section & Spontaneous labour & Oxytocin-induced labour & $\begin{array}{c}\text { P value* } \\
\text { (oxytocin-induced } v \\
\text { spontaneous labour) }\end{array}$ \\
\hline Packed cell volume & $0.52: 0.012(15)$ & $0.53 \div 0.013(40)$ & $0.47: 0.014(40)$ & 0.001 \\
\hline Erythrocyte deformability index $(\mathrm{ml} / \mathrm{min})$ & $0.83-0.03(15)$ & $0.81: 0.04(40)$ & $0.61 \div 0.06(40)$ & 0.001 \\
\hline Plasma bilirubin concentration $(\mu \mathrm{mol} / \mathrm{l})$ & $31=1 \cdot 2(15)$ & $33: 1 \cdot 3(40)$ & $38=1.5(40$ & $<0.001$ \\
\hline Plasma haptoglobin concentration $(\mathrm{g} / \mathrm{l})$ & . & $0.091: 0.024(25)$ & $0.023=0.006(25)$ & 0.01 \\
\hline Plasma lactate dehydrogenase activity (IU/1) & . & $223: 8(25)$ & $346-25(25)$ & $<0.001$ \\
\hline Plasma osmolality $(\mathrm{mmol} / \mathrm{kg}) \quad \ldots \quad \ldots$ & $286 \pm 4(15)$ & $290: 6(40)$ & $277 \div 6(40)$ & $<0.001$ \\
\hline
\end{tabular}

significant reduction in mean EDI $(P<0.001)$ and plasma osmolality $(\mathrm{P}<0.001)$.

In-vitro studies disclosed a time-related (fig 1) and dose-related (fig 2) effect of oxytocin on erythrocyte deformability. The duration of incubation affected the degree of charige in erythrocyte deformability. There was no difference between the oxytocin and control samples at one and two hours, but there was a significantly greater reduction in EDI in the oxytocin-treated samples at four hours $(P<0.05)$ and at six and eight hours $(P<0.001)$. Varying the dose of oxytocin in the erythrocyte suspensions showed that $100: \mathrm{UU} / \mathrm{ml}$ caused no significant decrease in deformability, but increasing the dose to $300 \mu \mathrm{U} / \mathrm{ml}$ caused a significant fall in EDI $(P<0.001)$, and a further decrease in EDI occurred at doses of 500 and $800 \mu \mathrm{U} / \mathrm{ml}$ $(\mathbf{P}<0.001)$

\section{Discussion}

The clinical findings of this study showed clear evidence of increased erythrocyte destruction during oxytocin-induced labour. The reduced packed cell volume and raised plasma bilirubin concentration after induced labour agreed with the findings of D'Souza et $a l,{ }^{4}$ and the low haptoglobin concentration and increased lactate dehydrogenase activity confirmed that accelerated erythrocyte destruction was taking place during induced labour. The plasma haptoglobin concentration in neonates is normally low, ${ }^{15}$ but the very low values observed in my series suggested increased haemolysis. The finding that fetal erythrocyte deformability is reduced after

*Derived with Student's $t$ test.
Conversion: SI to traditional units—Packed cell volume: $1 \cdot 0=1000^{\prime \prime}{ }_{0} . \mathrm{Plasma}$ bilirubin: $1: \mu \mathrm{mol} 1=0.06 \mathrm{mg} 100 \mathrm{ml}$. Plasma osmolality: $1 \mathrm{mmol} / \mathrm{kg}=1 \mathrm{mosmol} / \mathrm{kg}$. 
oxytocin induction and the knowledge that decreased deformability leads to accelerated haemolysis ${ }^{9-12}$ indicate the pathway of haemolysis in the induced group, and only the cause of the reduced deformability remains to be proved.

That it was oxytocin crossing the placenta that affected deformability was shown in the in-vitro studies, with the finding of both a time-related and dose-related effect of oxytocin on erythrocyte deformability in the range of oxytocin concentrations found in maternal blood during induction of labour with oxytocin. ${ }^{16}$ These in-vitro results also help to explain the clinical observations that the hyperbilirubinaemia after induction of labour is related to the dose and the duration of oxytocin administration. ${ }^{3}{ }^{4}$ The lowered plasma osmolality after induced labour agreed with the findings of Singhi and Singh ${ }^{8}$ and suggests that the vasopressin-like action of oxytocin ${ }^{17}$ causes activation of electrolyte and water transport across the erythrocyte membrane with consequent osmotic swelling, which is a wellrecognised cause of reduced erythrocyte deformability ${ }^{9}$ and leads to more rapid erythrocyte destruction. In the neonate, whose hepatic enzymes are unable to cope with the increased bilirubin production, clinical hyperbilirubinaemia ensues.

Oxytocin is an important therapeutic agent in obstetrics and probably its effect on erythrocytes cannot be prevented other than by keeping the total dose used to a minimum. The use of prenatal drug treatment with either phenobarbitone ${ }^{1 *}$ or antipyrene ${ }^{19}$ to activate fetal hepatic glucuronyltransferase and so increase the neonate's ability to eliminate bilirubin has been suggested, but it would be more logical to prevent the hyperbilirubinaemia by reducing the dose of oxytocin rather than treat it with potentially toxic drugs. department; to Mr H M Macdonald for his interest and encouragement; to the technical staff of the departments of medical illustration, clinical chemistry, haematology, and immunology at St James's Hospital; and to Miss $M$ Breeze and her nursing colleagues in the labour ward for their help.

\section{References}

${ }^{1}$ Friedman, L, et al, British Medical fournal, 1978, 1, 1235.

2 Chalmers, I, Campbell, H, and Turnbull, A C, British Medical fournal, $1975,2,116$.

${ }^{3}$ Beazley, J M, and Alderman, B, British fournal of Obstetrics and Gynaecology, 1975, 82, 265.

4 D'Souza, S W, et al, British fournal of Obstetrics and Gynaecology, 1979, $86,133$.

${ }^{5}$ Davies, D P, et al, British Medical fournal, 1973, 3, 476.

${ }^{6}$ Ghosh, A, and Hudson, F P, Lancet, 1972, 2, 823.

' Oski, F, American fournal of Diseases in Children, 1975, 129, 1139.

${ }^{8}$ Singhi, S, and Singh, M, British Medical Fournal, 1977, 2, 1028.

9 Weed, R I, and Reed, C F, American fournal of Medicine, 1966, 41, 681.

${ }^{10}$ LaCelle, P L, Seminars in Haematology, 1970, 7, 355.

${ }^{11}$ Rosenmund, A, Binswanger, U, and Straub, P W, Annals of Internal Medicine, 1975, 82, 460

12 Adams, K F, et al, Biochimica et Biophysica Acta, 1979, 550, 279.

${ }^{13}$ Buchan, P C, British fournal of Haematology. In press.

14 Wroblewski, F, and La Due, J S, Proceedings of the Society of Experimental Biology and Medicine, 1955, 90, 210.

${ }^{15}$ Lundh, B, Oski, F A, and Gardner, F H, Acta Paediatrica Scandinavica, 1970, 59, 121.

${ }^{16}$ Kumarensan, P, et al, American Fournal of Obstetrics and Gynecology, 1974, $119,215$.

17 Abdul-Karim, R W, and Rizk, P T, Obstetrical and Gynecological Survey, $1970,25,805$.

18 Trolle, D, Lancet, 1968, 2, 705.

19 Lewis, P J, and Friedman, L A, Lancet, 1979, 1, 300.

(Accepted 3 September 1979)

\title{
Role of residual insulin secretion in protecting against ketoacidosis in insulin-dependent diabetes
}

\author{
STEN MADSBAD, K GEORGE M M ALBERTI, CHRISTIAN BINDER, JACKIE M BURRIN, \\ OLE K FABER, THURE KRARUP， LISBETH REGEUR
}

British Medical fournal, 1979, 2, 1257-1259

\section{Summary and conclusions}

The role of preserved beta-cell function in preventing ketoacidosis in type $I$ insulin-dependent diabetes was assessed in eight patients with and seven patients without residual beta-cell function as determined from C-peptide concentrations. After 12 hours of insulin deprivation blood glucose, ketone-body, non-esterified fatty-acid, and glycerol concentrations were all signifi-

\footnotetext{
Hvidфre Hospital, Emiliekildevej 1, DK-2930, Klampenborg Denmark

STEN MADSBAD, MD, research fellow

CHRISTIAN BINDER, MD, chief physician

OLE K FABER, MD, senior registrar

THURE KRARUP, MD, registrar

LISBETH REGEUR, MD, registrar

Royal Victoria Infirmary, Newcastle upon Tyne NE1 4LP K GEORGE M M ALBERTI, FRCP, professor of clinical biochemistry JACKIE M BURRIN, PHD, research fellow in biochemistry
}

cantly higher in patients without beta-cell function than in those with residual secretion. Mean blood glucose concentrations reached $17 \cdot 2 \pm \mathrm{SE}$ of mean $1.3 \mathrm{mmol} / 1$ $(310 \pm 23 \mathrm{mg} / 100 \mathrm{ml})$ in the first group compared with $8.8 \pm 1.4 \mathrm{mmol} / 1(159 \pm 25 \mathrm{mg} / 100 \mathrm{ml})$ in the second $(P<0.01)$, while 3 -hydroxybutyrate concentrations rose to $5.5 \pm 0.5 \mathrm{mmol} / 1(57 \pm 5 \mathrm{mg} / 100 \mathrm{ml})$ and $1.4 \pm 0.3$ $\mathrm{mmol} / 1(15 \pm 3 \mathrm{mg} / 100 \mathrm{ml})$ in the two groups respectively $(\mathbf{P}<0.01)$. Individual mean $C$-peptide concentrations showed a significant inverse correlation with the final blood glucose values $(r=-0.91 ; P<0.02)$.

These findings strongly suggest that even minimal residual insulin secretion is important for metabolic wellbeing in diabetes and may prevent the development of severe ketoacidosis when insulin delivery is inadequate.

\section{Introduction}

Increased blood ketone-body concentrations and a tendency to develop severe ketoacidosis are characteristic of insulindependent type I diabetes mellitus. Nevertheless, patients vary widely in their susceptibility to ketoacidosis. Changes in catabolic hormone concentrations certainly influence the 